\title{
Particulate organic matter in sixteen Tuamotu atoll lagoons (French Polynesia)
}

\author{
Loïc Charpy ${ }^{1, *}$, Philippe Dufour ${ }^{1}$, Nicole Garcia ${ }^{2}$ \\ ${ }^{1}$ ORSTOM, Centre d'Océanologie de Marseille, Rue de la Batterie des Lions, F-13007 Marseille, France \\ ${ }^{2}$ LOB OSU, Luminy, 163 Av, de Luminy, F-13288 Marseille Cedex 09, France
}

\begin{abstract}
The standing stock and chemical composition of suspended particles were monitored in 16 Tuamotu atoll lagoons and surrounding oceanic water between 1983 and 1996. Temporal and spatial variability was estimated from 18 surveys performed in Takapoto. Atoll lagoon particulate organic matter (POM) concentrations were compared using data taken during the same months (March and November) and at the same time (morning). It appears that the lagoonal particulate organic carbon concentration depends on the latitude of each lagoon. We interpret this result as an influence of the waters deriving from the Peruvian and equatorial upwellings. Phytoplankton biomass (chlorophyll) concentration was inversely related to the water exchange between lagoon and ocean. Therefore, the best atolls for pearl oyster farming seem to be those located north of the Tuamotu Archipelago and with small exchange with the occan. POM concentration was 2 to 5 times higher in the atoll lagoons than in the surrounding oceanic water, with a higher $C: N$ ratio and a lower N:P ratio. The small size of organic particles $(70 \%<3 \mu \mathrm{m})$ and the low contribution of phytoplankton to particulate organic carbon (POC) ( 5 to $19 \%$ ) in the lagoons must be taken into account when calculating the potential of pearl oysters, which cannot exceed the nutritional potential of Tuamotu atoll lagoons
\end{abstract}

KEY WORDS: Particulate matter Atoll Geomorphology Pacific Carbon - Nitrogen Phosphorus . Pigments

\section{INTRODUCTION}

The lagoons of the Tuamotu archipelago play an important role in the French Polynesian economy. Cultured pearls from pearl oyster aquaculture in Tuamotu atolls are French Polynesia's major export $182.3 \%$ in 1987). This archipelago also accounts for a great part of the French Polynesian coastal fisheries ( $77 \%$ in 1987).

The level of exploitation of the Tuamotu lagoons depends on their distance from Tahiti, the most inhabited island of French Polynesia, and also on their natural marine resources. Many atolls do not have a natural population of pearl oysters and the presence of a passage linking ocean and lagoon is required in order to set up commercial fisheries.

Takapoto atoll pearl culture was begun on a regular basis in 1970. In 1974, this atoll was selected for the UNESCO Man and Biosphere program, which led an

\footnotetext{
·E-mail: charpy@orstom.rio.net
}

extensive knowledge of the lagoonal ecosystem. Pearl oyster Pinctada margaritifera aquaculture increased from 1970. However, the atoll was devastated in 1983 by a period of high cyclonic activity (Salvat \& Richard 1985). In 1985, a massive mortality of $P$. margaritifera showed that the biological conditions of the lagoon may have changed drastically. Therefore, a multidisciplinary program. (PGRN) was launched in 1991 to extend the knowledge of the lagoonal ecosystem, compare present environmental conditions with conditions existing at the beginning of the aquaculture activity and study the biology of $P$. margaritifera. In 1982 the ORSTOM ATOLL program was launched in Tikehau, an atoll without pearl oyster farming but with an important fishery. The CYEL program (1991 to 1996) is a continuation of the ATOLL program with a special focus on the pelagic microbial loop (Charpy 1992).

The extrapolation of the existing scientific knowledge on a few atoll lagoons to most of the others is impossible due to high geomorphological diversity. The objective of the research program 'TYPATOLL' 
(1994 to 1997) is to answer the question: 'How does the type of an atoll influence the structure and functioning of its lagoon?' (Dufour \& Harmelin-Vivien 1997).

The black lip pearl oyster is a filter feeder which obtains its food mainly from the particulate organic matter (POM). It is capable of efficiently filtering particles $>3 \mu \mathrm{m}$ (Dufour et al. 1996) Therefore, the study of the stock, quality and size of the POM is of great interest for the estimation of the lagoonal aquaculture potential, and also of the lagoon productivity.

Here, we present results on POM measurements performed in 16 Tuamotu atoll lagoons between 1983 and 1996. Results of such measurements from Tikehau lagoon were published in Charpy \& Charpy-Roubaud (1991) and we used these data for comparison with the other atolls. Temporal variability was estimated using the Takapoto data because we had at our disposal 19 surveys performed between 1991 and 1992. We have tried to estimate the influence of the geomorphology of atolls on the biological functioning of their lagoons by comparing the quality and the quantity of their POM. The ratio of particulate organic carbon to chlorophyll a (POC:chl a) was used to estimate the contribution of autotrophic organisms to suspended POM.

The location of the 16 prospected atolls appears in Fig. 1 and their characteristics in Table 1.

\section{MATERIAL AND METHODS}

Station location and sampling strategy. The sampling strategy used in the 3 programs is summarized in Table 2.

During the PGRN program, the lagoon of Takapoto was sampled monthly between June 1991 and November 1993 at Stns 1, 2 and 3, at 6:00,12:00 and 18:00 h at Stns 1 and 2 and at 6:00 and 12:00 h at Stn 3. Stn 1 is located close to the village and shows the maximum density of pearl oyster farms and spat collection. Stn 2 is located close to the main reef flat spillway. The Stn 3 area presents low density of spat collectors and only one pearl oyster farm.

Samples were collected during the TATU expedition of the ATOLL program in November 1985 in 3 atoll lagoons: Rangiroa, Taiaro and Toau.

During TYPATOLL, 3 expeditions (TY1, TY2, TY3) took place in 9 atoll lagoons in 1994 and 10 in 1995 and 1996. Sampling was undertaken in the morning at the surface $(0.5 \mathrm{~m}$ depth) in 5 areas located at the north, south, east, west and in the center of the lagoon and in 3 stations per area. Sampling was also done at $1.5 \mathrm{~m}$ above the bottom in the central station. Six oceanic stations were sampled at the surface in 1995 and 1996.



Fig. 1. Location of surveyed atolls and stations prospected in Takapoto, Rangiroa and Toau 
Table 1. Characteristics of the 16 prospected atolls during the ATOLL, PGRN and TYPATOLL programs. $\mathrm{S}_{\mathrm{at}}$ : atoll area; $\mathrm{S}_{\text {lan: }}$ lagoon area $\left(\mathrm{km}^{2}\right)$; NP: no. of passages; EAD: estimated average depth (m); Por.. calculated porosity; lnh.. no. of inhabitants Expl.: marine commercial exploitation

\begin{tabular}{|c|c|c|c|c|c|c|c|c|c|c|c|}
\hline Atoll & Latitude & Longitude & $S_{a 11}$ & $S_{\text {lag }}$ & NP & EAD & Por. & Inh. & Expl. & Source & Expedition \\
\hline Amanu & $17^{\circ} 50^{\prime} \mathrm{S}$ & $140^{\circ} 47^{\prime} \mathrm{W}$ & 343 & 315 & 3 & 45 & 21 & 100 & & & TY1 \\
\hline Haraiki & $17^{\circ} 28^{\prime} \mathrm{S}$ & $143^{\circ} 26^{\prime} \mathrm{W}$ & 24.6 & 10.4 & 1 & 10 & 19 & 20 & & & TY $1,2,3$ \\
\hline Hikueru & $17^{\circ} 35^{\prime} \mathrm{S}$ & $142^{\circ} 38^{\prime} \mathrm{W}$ & 107 & 82 & 0 & 25 & 18 & 300 & Pearl & & TY $1,2,3$ \\
\hline Hiti & $16^{\circ} 43^{\prime} \mathrm{S}$ & $144^{\circ} 06^{\prime} \mathrm{W}$ & 25 & 15 & 0 & 10 & 19 & 0 & & & TY2, 3 \\
\hline Kauehı & $15^{\circ} 50^{\prime} \mathrm{S}$ & $145^{\circ} 09^{\prime} \mathrm{W}$ & 343 & 315 & 1 & 50 & 22 & 200 & Pearl & & TY $1,2,3$ \\
\hline Marokau & $18^{\circ} 03^{\prime} \mathrm{S}$ & $142^{\circ} 16^{\prime} \mathrm{W}$ & 256 & 217 & 1 & 30 & 17 & 50 & & & TY2, 3 \\
\hline Nihiru & $16^{\circ} 41^{\prime S}$ & $142^{\circ} 50^{\prime} \mathrm{W}$ & 100 & 80 & 0 & 20 & 25 & 20 & & & TY $1,2,3$ \\
\hline Rangiroa & $15^{\circ} 10^{\prime} \mathrm{S}$ & $147^{\circ} 40^{\prime} \mathrm{W}$ & 17621 & 1592 & 2 & 25 & 22 & 2000 & Fish, pearl & $\begin{array}{l}\text { Stoddart (1969) } \\
\text { Ricard (1985) }\end{array}$ & TATU \\
\hline Reka-Reka & $16^{\circ} 50^{\prime} \mathrm{S}$ & $141^{\circ} 55^{\prime} \mathrm{W}$ & 52 & 0.7 & 0 & 1 & 2 & 0 & & & TY $1,2,3$ \\
\hline Taiaro & $15^{\circ} 45^{\prime} \mathrm{S}$ & $144^{\circ} 38^{\prime} \mathrm{W}$ & 17.3 & 11.8 & 0 & 15 & 1 & 3 & & $\begin{array}{l}\text { Chevallier \& Salvat (1976) } \\
\text { Poli \& Salvat (1976) }\end{array}$ & $\begin{array}{l}\text { TATU, } \\
\text { TY } 2,3\end{array}$ \\
\hline Takapoto & $14^{\circ} 30^{\prime} \mathrm{S}$ & $145^{\circ} 20^{\prime} \mathrm{W}$ & 104 & 81 & 0 & 25 & 2 & 500 & Pearl & Salvat \& Richard (1985) & PGRN, \\
\hline Tekokota & $17^{\circ} 19^{\prime} \mathrm{S}$ & $142^{\circ} 34^{\prime} W$ & 7.3 & 5.1 & 1 & 3 & 59 & 0 & & & TY $1,2,3$ \\
\hline Tepoto Sud & $16^{\circ} 49^{\prime} \mathrm{S}$ & $144^{\circ} 17^{\prime} \mathrm{W}$ & 6.2 & 1.6 & 1 & 5 & 15 & 0 & & & TY $1,2,3$ \\
\hline Tikehau & $15^{\circ} 00^{\prime} \mathrm{S}$ & $148^{\circ} 10^{\prime} \mathrm{W}$ & 448 & 394 & 1 & 25 & 20 & 250 & Fish & Intes et al. (1994) & ATOLL \\
\hline Toau & $15^{\circ} 50^{\prime} \mathrm{S}$ & $146^{\circ} 00^{\prime} \mathrm{W}$ & 652 & 561 & 2 & 25 & 39 & 15 & & & TATU \\
\hline Tuanake & $16^{\circ} 38^{\prime} \mathrm{S}$ & $144^{\circ} 11^{\prime} \mathrm{W}$ & 38 & 26 & 1 & 25 & 24 & 0 & & & TY1 \\
\hline
\end{tabular}

Water samples were taken with a 51 Niskin bottle fitted with a Teflon spring.

Chemical analyses of seston. During the pre-1995 expeditions, 500 to $1000 \mathrm{ml}$ of sea water was filtered through a $25 \mathrm{~mm}$ diameter Whatman GF/F processed filter (precombusted for $4 \mathrm{~h}$ at $450^{\circ} \mathrm{C}$ and precleaned with $1 \mathrm{~N} \mathrm{HCl}$ ) for particulate organic carbon (POC), nitrogen (PON) and phosphorus (POP) analysis. POC and $\mathrm{PON}$ concentrations were determined after rinsing the filter with $20 \mathrm{ml}$ of $\mathrm{HCl}(0.1 \mathrm{~N})$ with a $\mathrm{CHN}$ analyzer (Gordon \& Sutcliffe 1973). POP was oxidized with persulfate at $110^{\circ} \mathrm{C}$ for $1.5 \mathrm{~h}$ (Menzel \& Corwin 1965) and phosphate concentrations were subsequently analyzed by spectrophotometry (Strickland \& Parsons 1972).

After 1995, particulate matter samples were collected on precombusted $\left(450^{\circ} \mathrm{C}\right.$ for $\left.24 \mathrm{~h}\right) \mathrm{GF} / \mathrm{F}$ glass fiber filters (25 $\mathrm{mm}$ diameter) by filtering $500 \mathrm{ml}$ (for phosphorus) and $1000 \mathrm{ml}$ (for carbon and nitrogen) of sea water. In oceanic areas, $1000 \mathrm{ml}$ and $2000 \mathrm{ml}$ were filtered respectively. Particulate $\mathrm{C}$ and $\mathrm{N}$ concentrations were determined with a LECO $800 \mathrm{CHN}$ analyzer calibrated with glycine samples. Two aliquots were necessary to obtain the organic fraction values (POC and PON). The first filter was used to measure the total (organic + inorganic) carbon and nitrogen and the second one (same filtration and storage conditions) was combusted at $450^{\circ} \mathrm{C}$ for $24 \mathrm{~h}$ to eliminate the organic and keep the inorganic fraction. The difference between the 2 results gives us the $\mathrm{POC}$ and PON concentrations. POP was oxidized with persulfate at $120^{\circ} \mathrm{C}$ for $30 \mathrm{~min}$ (PujoPay \& Raimbault 1994). The phosphate concentrations were determined in a Technicon Auto Analyzer (Tréguer \& Le Corre 1975).

For chlorophyll determinations, $250 \mathrm{ml}$ of the water sample was filtered through a GF/F filter or a Nuclepore $3 \mu \mathrm{m}$ filter. Pressure heads during fractionation never exceeded $0.004 \mathrm{~atm}$. Fluorescence was measured before and after acidification with $50 \mu l$ of $1 \mathrm{~N}$ $\mathrm{HCl}$ (Yentsch \& Menzel 1963). The fluorometer was previously calibrated using Sigma chlorophyll a standard.

Size structure. To measure the size structure of suspended particles, water samples were successively filtered through a $3 \mu \mathrm{m}$ filter (Nuclepore), then through a GF/F filter. The percentage of POC, PON and POP in the $<3 \mu \mathrm{m}$ fraction was calculated by comparing with the direct measurement through the GF/F filter. The chlorophyll concentration of the $>3 \mu \mathrm{m}$ fraction was measured directly on the $25 \mathrm{~mm}$ diameter $3 \mu \mathrm{m}$ Nuclepore filter.

Table 2. Sampling strategy during the expeditions in the 16 prospected atolls. $\mathrm{N}_{\text {stat }}$ no. of prospected stations per lagoon

\begin{tabular}{|lllrl|}
\hline Program & Expedition & \multicolumn{1}{c|}{ Date } & $N_{\text {stat }}$ & \multicolumn{1}{c|}{ Depth $(\mathrm{m})$} \\
\hline ATOLL & Surveys & Oct 1983-Jan 1987 & 48 & $0,5,10,15,20,25,30$ \\
ATOLL & TATU & Nov 1985 & 2 & $0,5,10,15,20$ \\
TYPATOLL & TY1 & Nov 1994 & 5 & 0, bottom \\
TYPATOLL & TY2 & Nov 1995 & 5 & 0, bottom \\
TYPATOLL & TY3 & Mar 1996 & 5 & 0, bottom \\
PGRN & Surveys & Jun 1991-Dec 1992 & 3 & 0,5, bottom \\
& & & & \\
\hline
\end{tabular}




\section{RESULTS}

\section{Takapoto atoll}

Results of the 836 analyses of POM concentrations in Takapoto between June 1991 and December 1992, with all stations and depth pooled, appear in Fig 2. POC and PON concentrations varied between 41 and $280 \mathrm{mg} \mathrm{m}^{-3}$ and between 7 and $52 \mathrm{mg} \mathrm{m}^{-3}$, respectively. They presented a similar pattern, with a net increase during the months of December, January and February 1991, which corresponds to the rainy season. POP concentration varied between 0.6 and $2.3 \mathrm{mg} \mathrm{m}^{-3}$. Chlorophyll concentration varied between 0.09 and $0.55 \mathrm{mg} \mathrm{m}^{-3}$. A net increase was observed in October 1992. All POM parameters were higher in 1992 than in 1991 The results of 693 filtering experiments performed in 1991 and 1992 indicate that $70 \%$ of the POM passed through a $3 \mu \mathrm{m}$ Nuclepore filter. This percentage was higher during March and April 1992 for POC and PON

The Takapoto data were first analyzed with a 4-way analysis of variance (Table 3 ). Since the p-values of the survey factor are less than 0.05 for all POM parameters, sampling date has a statistically significant effect on POM concentration at the $95 \%$ confidence level. Station location also has a statistically significant effect on chl a and POC concentrations. The sampling hour and the depth have a significant effect but only on chl a concentrations.

\section{TATU expedition}

Results are summarized in Table 4.

In Rangiroa lagoon, Stn TA1 presented lower POP and chlorophyll levels than Stn TA2, but similar POC and PON. No depth influence was observed in POM concentration. Average $\mathrm{C}: \mathrm{N}, \mathrm{C}: \mathrm{P}$ and $\mathrm{C}$ :chl a ratios were respectively $10.0 \pm 0.6(n=9), 91 \pm 8(n=9)$ and $1728 \pm 137(n=9)$.

For Taiaro, we have only surface data. The 3 prospected stations showed similar POM concentrations.
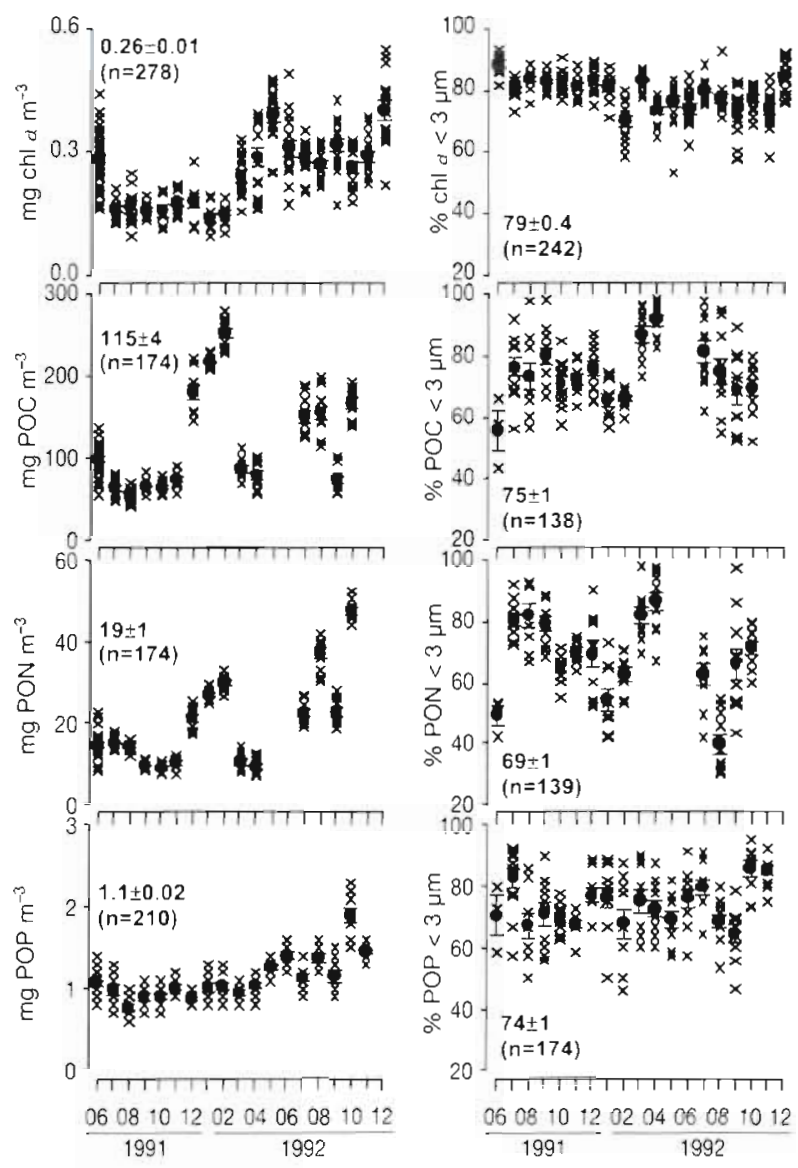

Fig. 2. Averages $\pm \mathrm{SE}$ of particulate organic carbon, nitrogen, phosphorus and chlorophyll (chl a) concentrations and percentages of POM $<3 \mu \mathrm{m}$ in Takapoto lagoon between June 1991 and December 1992

Average $\mathrm{C}: \mathrm{N}, \mathrm{C}: \mathrm{P}$ and $\mathrm{C}: \mathrm{chl}$ a ratios were respectively $14.6 \pm 2.1(n=3), 91 \pm 10(n=3)$ and $1112 \pm 31(n=3)$

In Toau, Stn TA6, located close to the passage, showed lower POC and PON concentrations than Stn TA7 but a higher chlorophyll concentration. Average $\mathrm{C}: \mathrm{N}, \mathrm{C}: \mathrm{P}$ and $\mathrm{C}: \mathrm{chl}$ a ratios were respectively $7.1 \pm 0.6(n=8), 71 \pm 7(n=8)$ and $1221 \pm 234(n=8)$.

No size fractionation was done during the TATU expedition.

Table 3. F-values and degrees of freedom (df) derived by a 4-way analysis of vanance (ANOVA) of POM characteristics from lagoon waters in Takapoto atoll

\begin{tabular}{|c|c|c|c|c|c|c|c|c|c|c|c|}
\hline & $\mathrm{df}$ & Chla & POC & PON & $\mathrm{POP}$ & Chl a & $\begin{array}{l}6<3 \mu \\
\text { POC }\end{array}$ & PON & $\mathrm{C}: \mathrm{N}$ & $\mathrm{C}: \mathrm{P}$ & C:chl a \\
\hline Survey & $18 / 277$ & $27.8^{\circ}$ & $128.5^{\circ}$ & $215.8^{\circ}$ & $29.7^{\circ}$ & $9.6^{\circ}$ & $5.8^{\circ}$ & $15.6^{\circ}$ & $81.2^{\circ}$ & $75.9^{\circ}$ & $83.3^{\circ}$ \\
\hline Hour & $2 / 277$ & $9.0^{\circ}$ & 2.8 & 2.9 & 0.6 & $11.8^{\circ}$ & 0.1 & 0.0 & 1.5 & 1.6 & 0.4 \\
\hline Station & $2 / 277$ & $14.6^{\circ}$ & $3.3^{\circ}$ & 1.1 & 0.4 & 0.4 & 0.4 & 0.0 & $6.2^{\circ}$ & 1.4 & 0.5 \\
\hline Depth & $5 / 277$ & $3.3^{\circ}$ & 0.5 & 1.2 & 0.7 & 2.2 & 0.5 & 1.0 & 1.2 & 0.3 & 0.2 \\
\hline$\cdot p<0.05$ & & & & & & & & & & & \\
\hline
\end{tabular}


Table 4. POM ( $\left.\mathrm{mg} \mathrm{m}^{-3}\right)$ and average \pm standard error in the 3 prospected atoll lagoons during the TATU expedition (November 1985)

\begin{tabular}{|c|c|c|c|c|c|c|}
\hline Atoll & Stn & Depth (m) & $\mathrm{POC}$ & PON & POP & Chl a \\
\hline \multirow[t]{3}{*}{ Rangiroa } & TA1 & $\begin{array}{r}0 \\
6 \\
10 \\
15 \\
22\end{array}$ & $\begin{array}{l}214 \\
260 \\
220 \\
194 \\
222\end{array}$ & $\begin{array}{l}25 \\
29 \\
26 \\
21 \\
27\end{array}$ & $\begin{array}{l}2.0 \\
3.4 \\
2.5 \\
1.9 \\
1.8\end{array}$ & $\begin{array}{l}0.15 \\
0.14 \\
0.12 \\
0.12 \\
0.13\end{array}$ \\
\hline & TA2 & $\begin{array}{r}0 \\
6 \\
10 \\
15\end{array}$ & $\begin{array}{l}268 \\
253 \\
286 \\
225\end{array}$ & $\begin{array}{l}29 \\
25 \\
30 \\
27\end{array}$ & $\begin{array}{l}3.9 \\
4.0 \\
5.0 \\
4.4\end{array}$ & $\begin{array}{l}0.18 \\
0.19 \\
0.20 \\
0.21\end{array}$ \\
\hline & & $\begin{array}{c}\text { Average } \\
\mathrm{N}\end{array}$ & $\begin{array}{c}238 \pm 9 \\
9\end{array}$ & $\begin{array}{c}27 \pm 1 \\
9\end{array}$ & $\begin{array}{c}3.2 \pm 0.4 \\
9\end{array}$ & $\begin{array}{c}0.16 \pm 0.01 \\
9\end{array}$ \\
\hline \multirow[t]{2}{*}{ Tairao } & $\begin{array}{l}\text { TA3 } \\
\text { TA4 } \\
\text { TA5 }\end{array}$ & $\begin{array}{l}0 \\
0 \\
0\end{array}$ & $\begin{array}{l}197 \\
242 \\
191\end{array}$ & $\begin{array}{l}15 \\
13 \\
16\end{array}$ & $\begin{array}{l}2.4 \\
2.2 \\
2.4\end{array}$ & $\begin{array}{l}0.17 \\
0.23 \\
0.17\end{array}$ \\
\hline & & $\begin{array}{c}\text { Average } \\
\mathrm{N}\end{array}$ & $\begin{array}{c}210 \pm 16 \\
3\end{array}$ & $\begin{array}{c}15 \pm 1 \\
3\end{array}$ & $2.3 \pm 0.1$ & $0.19 \pm 0.02$ \\
\hline \multirow[t]{3}{*}{ Toau } & TA6 & $\begin{array}{r}0 \\
6 \\
10 \\
15\end{array}$ & $\begin{array}{r}88 \\
155 \\
103 \\
120\end{array}$ & $\begin{array}{l}13 \\
25 \\
23 \\
15\end{array}$ & $\begin{array}{l}2.1 \\
1.7 \\
2.1 \\
2.0\end{array}$ & $\begin{array}{l}0.16 \\
0.16 \\
0.18 \\
0.18\end{array}$ \\
\hline & TA7 & $\begin{array}{r}0 \\
6 \\
10 \\
15\end{array}$ & $\begin{array}{l}145 \\
170 \\
239 \\
244\end{array}$ & $\begin{array}{l}15 \\
28 \\
32 \\
31\end{array}$ & $\begin{array}{l}1.5 \\
1.8 \\
3.4 \\
3.9\end{array}$ & $\begin{array}{l}0.11 \\
0.11 \\
0.14 \\
0.10\end{array}$ \\
\hline & & $\begin{array}{c}\text { Average } \\
\mathrm{N}\end{array}$ & $\begin{array}{c}158 \pm 21 \\
8\end{array}$ & $\begin{array}{c}23 \pm 3 \\
8\end{array}$ & $\frac{2.3 \pm 0.3}{8}$ & $0.14 \pm 0.01$ \\
\hline
\end{tabular}

\section{Dry season (TY3 expedition)}

The atolls may be separated into 3 groups according to their average POM concentrations (Fig. 4): (1) Haraiki, Reka-Reka, Taiaro; (2) Hikueru, Hiti, Marokau, Nihiru, Tepoto; and (3) Kauehi, Tekokota. The chl a concentration observed in Tekokota lagoon was lower than the ocean concentration. In surface oceanic waters, the POM concentrations were $0.04 \pm 0.00$ $\mathrm{mg} \mathrm{chl} \mathrm{a} \mathrm{m} \mathrm{m}^{-3}, 49 \pm 5 \mathrm{mg} \mathrm{C} \mathrm{m} \mathrm{m}^{-3}, 12.8 \pm$ $1.3 \mathrm{mg} \mathrm{N} \mathrm{m}^{-3}, 0.4 \pm 0.0 \mathrm{mg} \mathrm{P} \mathrm{m}^{-3}$. The percentages of chl $a<3 \mu \mathrm{m}$ were above $70 \%$ except in Taiaro (53\%), Tepoto (39\%) and Tekokota (26\%). The percentages of $\mathrm{POC}$ and $\mathrm{PON}$ $<3 \mu \mathrm{m}$ were all above $60 \%$.

The same atolls and the same stations were prospected during the TY2 (November, beginning of the rainy season) and TY3 (March to April, beginning of dry season) expeditions These data were analyzed with a 1 -way analysis of variance (Table 5). The factor 'expedition' has a significant effect on chl $a$ and PON concentrations and on the percentages of chl $a$ and $\mathrm{POC}<3 \mu \mathrm{m}$. Concentrations

\section{Rainy season (TY1 and TY2 expeditions)}

The atolls may be separated into 4 groups according to their average POM concentrations (Fig. 3): (1) RekaReka; (2) Taiaro, Tepoto; (3) Amanu, Haraiki, Hikueru, Hiti, Kauehi, Marokau, Nihiru, Tuanake; and (4) Tekokota. The chl a observed in Tepoto lagoon was of the same order of magnitude as in group 3 but POC, PON and $P O P$ concentrations were in the range of values observed in group 2. In surface oceanic waters, the POM concentrations were $0.06 \pm 0.01 \mathrm{mg} \mathrm{chl} \mathrm{a} \mathrm{m}^{-3}$, $42 \pm 9 \mathrm{mg} \mathrm{C} \mathrm{m}{ }^{-3}, 6.5 \pm 1.2 \mathrm{mg} \mathrm{N} \mathrm{m}^{-3}, 0.8 \pm 0.1 \mathrm{mg} \mathrm{P} \mathrm{m}^{-3}$. The percentages of chl a $<3 \mu \mathrm{m}$ were above $70 \%$ except in Taiaro $(58 \%)$ and Tekokota (58\%). The percentages of POC and PON $<3 \mu \mathrm{m}$ were all above $60 \%$ were higher but percentages $<3 \mu \mathrm{m}$ were lower during the TY3 expedition.

\section{DISCUSSION}

\section{Temporal and spatial variability}

In Takapoto, we observed a seasonal variability with an increase of POM concentration during the austral summer, which corresponds to the rainy and cyclonic period. Indeed, we observed at this period a higher exchange of water between lagoon and ocean due to wave action. The wind also produces a homogenization of the water column and a resuspen-

Table 5. F-values and degrees of freedom (df) derived by a 1 -way analysis of variance (ANOVA) of POM characteristics from TY2 and TY 3 expeditions

\begin{tabular}{|c|c|c|c|c|c|c|c|c|c|}
\hline & Chl a & POC & PON & POP & $\begin{array}{r}\% \\
\text { Chl a }\end{array}$ & ${ }_{\mathrm{POC}}$ & $\mathrm{C}: \mathrm{N}$ & $C: P$ & C:chl a \\
\hline $\begin{array}{l}\text { F-values } \\
\text { df } \\
\cdot p<0.05\end{array}$ & $\begin{array}{c}4.2^{\circ} \\
1 / 106\end{array}$ & $\begin{array}{c}0.8 \\
1 / 105\end{array}$ & $\begin{array}{l}16.2^{\circ} \\
1 / 106\end{array}$ & $\begin{array}{c}2.0 \\
1 / 97\end{array}$ & $\begin{array}{c}3.9 \\
1 / 67\end{array}$ & $\begin{array}{c}13.7^{\circ} \\
1 / 87^{\circ}\end{array}$ & $\begin{array}{l}15.8^{\circ} \\
1 / 105\end{array}$ & $\begin{array}{l}6.7^{\circ} \\
1 / 94\end{array}$ & $\begin{array}{c}0.4^{\circ} \\
1 / 103\end{array}$ \\
\hline
\end{tabular}




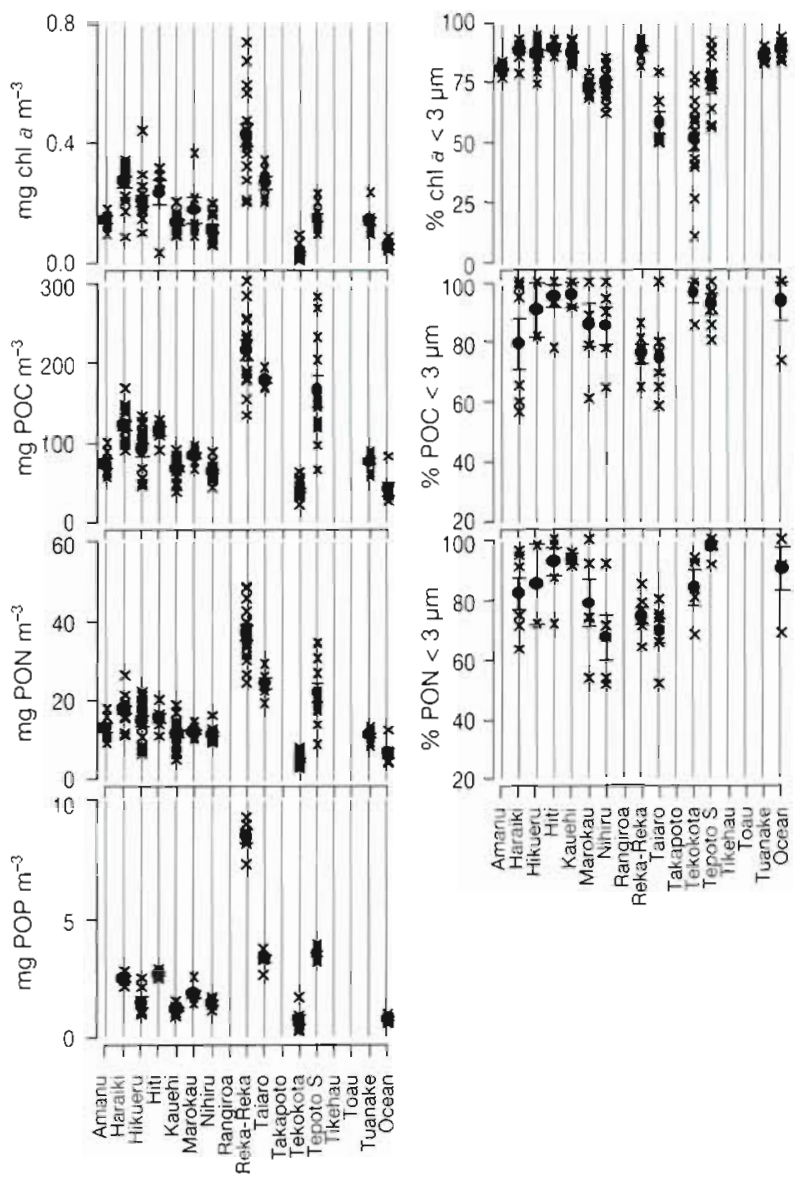

Fig. 3. Averages \pm SE of particulate organic carbon, nitrogen, phosphorus and chl a concentrations and percentages of POM $<3 \mu \mathrm{m}$ in 12 of the 1.6 prospected Tuamotu atoll lagoons and oceanic surface waters (rainy season)

sion of benthic organic matter. Torréton \& Dufour (1997) observed a significant correlation between wind speed and bacterial abundance in Tikehau lagoon. They consider that the most likely explanation for an increase of bacterial abundance without a concomitant increase in bacterial activity is sediment resuspension. POM concentration in 1991 appeared to be exceptionally low. Indeed other sampling performed in 1993 and 1994 (Charpy 1996) showed that chl a concentrations observed in these years are similar to chl a concentrations observed in 1992. The low POM content observed in 1991 cannot be explained at present.

The chl a concentration measured at Stn 1 in Takapoto lagoon was two-thirds that of the concentrations observed at Strns 2 and 3. Stn 1 is located close to the village and may be contaminated by sewage.

Chl a concentrations measured in the evening were twice as high as those measured in the morning or at noon. This reflects the important productivity of phyto-
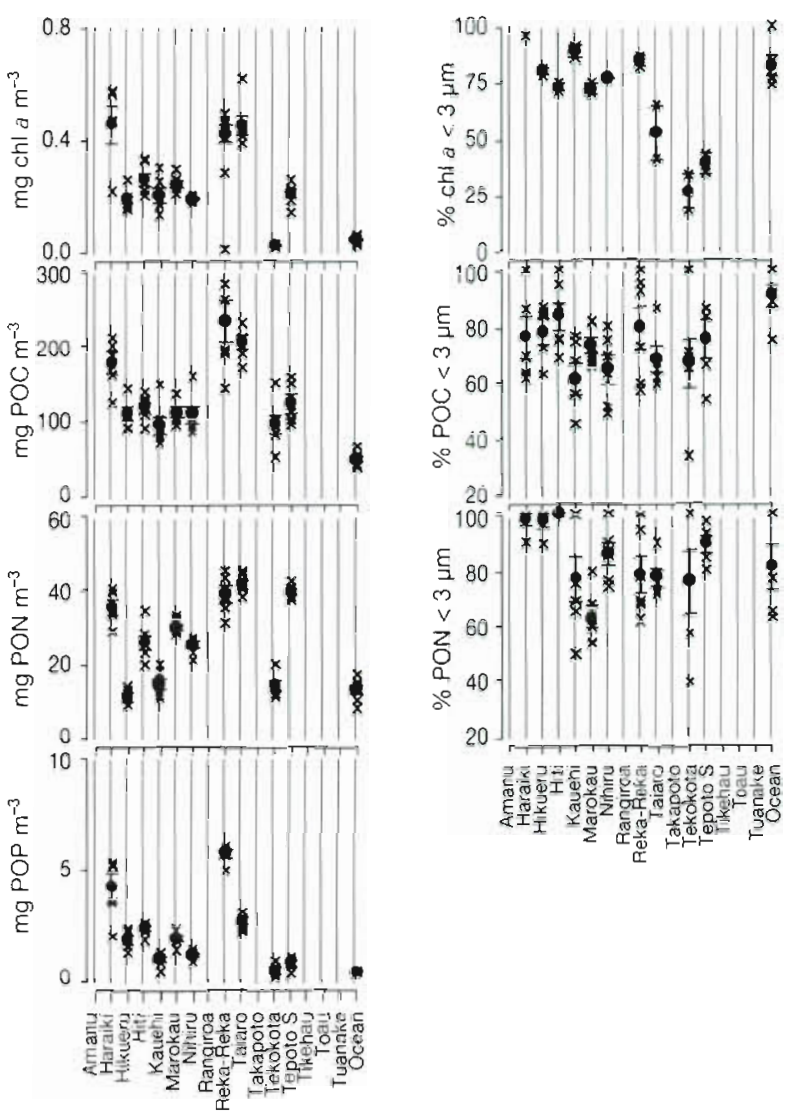

Fig. 4. Averages \pm SE of particulate organic carbon, nitrogen, phosphorus and chl a concentrations and percentages of $\mathrm{POM}$ $<3 \mu \mathrm{m}$ in 10 of the 16 Tuamotu atoll lagoons and oceanic surface waters (dry season)

plankton with a turnover rate of $1 \mathrm{~d}^{-1}$ (Charpy 1996). Microscopic observations made by Charpy et al. (1992) have shown that Takapoto lagoon phytoplankton is dominated by Synechococcus and that all cells were dividing in the evening

The depth effect was observed under exceptionally calm conditions when the biomass and production maxima were found between 15 and $25 \mathrm{~m}$ (Charpy 1996, Charpy \& Blanchot 1996).

\section{Comparison between lagoons}

To compare all atoll lagoon POM concentrations, we used data from the TATU expedition (November 1985), TYPATOLL expeditions (March and November), from Takapoto atoll surveys (1991 to 1992) and from Tikehau atoll surveys (1982 to 1987). To remove the sampling time effect and decrease the seasonal variability, we only used data obtained from sampling performed in the morning and during the months of March and November (Table 6) 
Table 6. Summary of POM data from 16 Tuamotu atolls $\left(\mathrm{mg} \mathrm{m}^{-3}\right)$. Data from samples collected in the morning and during the months of March and November

\begin{tabular}{|c|c|c|c|c|c|c|c|c|c|}
\hline Atoll & $\mathrm{POC}$ & PON & POP & $\mathrm{Chl} \mathrm{a}$ & $\mathrm{C}: \mathrm{N}$ & $N: P$ & C:chl a & $\mathrm{Chl} a<3 \mu \mathrm{m}(\%)$ & $C<3 \mu \mathrm{m}(\%)$ \\
\hline Amanu & $\begin{array}{r}73 \pm 6 \\
N=7\end{array}$ & $\begin{array}{l}13 \pm 1 \\
N=7\end{array}$ & & $\begin{aligned} 0.14 & \pm 0.01 \\
N & =9\end{aligned}$ & $\begin{aligned} 5.8 & \pm 0.4 \\
N & =7\end{aligned}$ & & $\begin{array}{c}506 \pm 40 \\
N=7\end{array}$ & $\begin{array}{l}81 \pm 1 \\
N=9\end{array}$ & \\
\hline Haraiki & $\begin{aligned} 135 & \pm 8 \\
N & =19\end{aligned}$ & $\begin{aligned} 22 & \pm 2 \\
N & =19\end{aligned}$ & $\begin{array}{c}3.4 \pm 0.4 \\
N=10\end{array}$ & $\begin{aligned} 0.32 & \pm 0.03 \\
N & =20\end{aligned}$ & $\begin{array}{c}6.4 \pm 0.3 \\
N=19\end{array}$ & $\begin{array}{c}8.2 \pm 0.9 \\
N=10\end{array}$ & $\begin{array}{r}483 \pm 57 \\
N=19\end{array}$ & $\begin{array}{c}89 \pm 0.9 \\
N=16\end{array}$ & $\begin{array}{l}78 \pm 5 \\
N=11\end{array}$ \\
\hline Hikueru & $\begin{aligned} 97 & \pm 6 \\
N & =20\end{aligned}$ & $\begin{array}{l}14 \pm 1 \\
N=21\end{array}$ & $\begin{array}{c}1.7 \pm 0.2 \\
N=12\end{array}$ & $\begin{aligned} 0.20 & \pm 0.02 \\
N & =21\end{aligned}$ & $\begin{aligned} 7.5 & \pm 0.6 \\
N & =20\end{aligned}$ & $\begin{array}{c}6.4 \pm 0.5 \\
N=12\end{array}$ & $\begin{array}{r}513 \pm 41 \\
N=20\end{array}$ & $\begin{array}{l}86 \pm 1 \\
N=17\end{array}$ & $\begin{array}{l}82 \pm 4 \\
N=7\end{array}$ \\
\hline Hiti & $\begin{aligned} 116 & \pm 4 \\
N & =12\end{aligned}$ & $\begin{aligned} 20 & \pm 2 \\
N & =12\end{aligned}$ & $\begin{aligned} 2.5 & \pm 0.1 \\
N & =12\end{aligned}$ & $\begin{aligned} 0.25 & \pm 0.02 \\
N & =12\end{aligned}$ & $\begin{aligned} 6.1 & \pm 0.5 \\
N & =12\end{aligned}$ & $\begin{array}{c}8.4 \pm 0.9 \\
N=12\end{array}$ & $\begin{array}{c}714 \pm 267 \\
N=12\end{array}$ & $\begin{array}{r}85 \pm 3 \\
N=8\end{array}$ & $89 \pm 3$ \\
\hline Kauehi & $\begin{array}{l}75 \pm 5 \\
N=21\end{array}$ & $\begin{array}{l}13 \pm 1 \\
N=21\end{array}$ & $\begin{array}{c}1.1 \pm 0.1 \\
N=12\end{array}$ & $\begin{aligned} 0.15 & \pm 0.01 \\
N & =21\end{aligned}$ & $\begin{array}{c}6.2 \pm 0.3 \\
N=21\end{array}$ & $\begin{array}{c}11.5 \pm 2.1 \\
\mathrm{~N}=12\end{array}$ & $\begin{array}{r}513 \pm 32 \\
N=21\end{array}$ & $\begin{array}{l}88 \pm 1 \\
N=17\end{array}$ & $\begin{array}{l}70 \pm 7 \\
N=8\end{array}$ \\
\hline Marokau & $\begin{array}{l}98 \pm 5 \\
N=12\end{array}$ & $\begin{aligned} 21 & \pm 3 \\
N & =12\end{aligned}$ & $\begin{array}{c}1.9 \pm 0.1 \\
N=12\end{array}$ & $\begin{aligned} 0.21 & \pm 0.02 \\
N & =12\end{aligned}$ & $\begin{aligned} 5.4 & \pm 0.5 \\
N & =12\end{aligned}$ & $\begin{aligned} 11.2 & \pm 1.6 \\
N & =12\end{aligned}$ & $\begin{array}{r}524 \pm 48 \\
N=12\end{array}$ & $\begin{array}{r}73 \pm 1 \\
N=8\end{array}$ & $\begin{array}{l}79 \pm 4 \\
N=11\end{array}$ \\
\hline Nihiru & $\begin{array}{l}77 \pm 6 \\
N=20\end{array}$ & $\begin{array}{l}15 \pm 1 \\
N=20\end{array}$ & $\begin{array}{c}1.3 \pm 0.1 \\
N=12\end{array}$ & $\begin{aligned} 0.13 & \pm 0.01 \\
N & =21\end{aligned}$ & $\begin{array}{c}5.2 \pm 0.2 \\
\mathrm{~N}=2.0\end{array}$ & $\begin{array}{c}14.9 \pm 2.1 \\
\mathrm{~N}=12\end{array}$ & $\begin{array}{r}624 \pm 48 \\
N=20\end{array}$ & $\begin{array}{l}75 \pm 1 \\
N=17\end{array}$ & $\begin{aligned} 74 & \pm 5 \\
N & =11\end{aligned}$ \\
\hline Rangiroa & $\begin{array}{r}238 \pm 9 \\
N=9\end{array}$ & $\begin{aligned} 27 & \pm 1 \\
N & =9\end{aligned}$ & $\begin{array}{c}3.2 \pm 0.4 \\
N=9\end{array}$ & $\begin{aligned} 0.16 & \pm 0.01 \\
N & =9\end{aligned}$ & $\begin{aligned} 9.0 & \pm 0.2 \\
N & =9\end{aligned}$ & $\begin{aligned} 9.3 & \pm 1.1 \\
N & =9\end{aligned}$ & $\begin{array}{c}1529 \pm 84 \\
N=9\end{array}$ & & \\
\hline Reka-Reka & $\begin{array}{r}221 \pm 12 \\
N=21\end{array}$ & $\begin{array}{l}37 \pm 1 \\
N=21\end{array}$ & $\begin{array}{c}7.1 \pm 0.4 \\
N=12\end{array}$ & $\begin{array}{c}0.43 \pm 0.03 \\
N=21\end{array}$ & $\begin{array}{c}5.9 \pm 0.2 \\
N=21\end{array}$ & $\begin{array}{c}5.9 \pm 0.4 \\
N=12\end{array}$ & $\begin{array}{r}548 \pm 35 \\
N=21\end{array}$ & $\begin{array}{l}88 \pm 1 \\
N=12\end{array}$ & $\begin{array}{l}78 \pm 4 \\
N=12\end{array}$ \\
\hline Taiaro & $\begin{aligned} 195 & \pm 6 \\
N & =15\end{aligned}$ & $\begin{array}{l}29 \pm 3 \\
N=15\end{array}$ & $\begin{aligned} 2.9 & \pm 0.1 \\
N & =15\end{aligned}$ & $\begin{aligned} 0.32 & \pm 0.03 \\
N & =15\end{aligned}$ & $\begin{aligned} 7.9 & \pm 1 \\
\mathrm{~N} & =15\end{aligned}$ & $\begin{aligned} 10.5 & \pm 1.2 \\
N & =15\end{aligned}$ & $\begin{array}{r}683 \pm 67 \\
N=15\end{array}$ & $\begin{aligned} 57 & \pm 5 \\
N & =8\end{aligned}$ & $\begin{array}{l}72 \pm 4 \\
N=11\end{array}$ \\
\hline Takapoto & $\begin{array}{l}82 \pm 3 \\
N=18\end{array}$ & $\begin{array}{l}10 \pm 1 \\
N=18\end{array}$ & $\begin{aligned} 1.1 & \pm 0.04 \\
N & =30\end{aligned}$ & $\begin{array}{c}0.23 \pm 0.01 \\
\mathrm{~N}=30\end{array}$ & $\begin{array}{c}7.9 \pm 0.2 \\
N=18\end{array}$ & $\begin{aligned} 10.8 & \pm 0.4 \\
N & =18\end{aligned}$ & $\begin{array}{r}441 \pm 22 \\
N=18\end{array}$ & $\begin{array}{l}80 \pm 1 \\
N=30\end{array}$ & $\begin{array}{l}80 \pm 2 \\
N=18\end{array}$ \\
\hline Tekokota & $\begin{array}{l}56 \pm 7 \\
N=21\end{array}$ & $\begin{array}{l}8 \pm 1 \\
N=21\end{array}$ & $\begin{array}{c}0.6 \pm 0.1 \\
N=11\end{array}$ & $\begin{aligned} 0.03 & \pm 0.01 \\
N & =19\end{aligned}$ & $\begin{aligned} 8.1 & \pm 0.5 \\
N & =21\end{aligned}$ & $\begin{array}{c}12.5 \pm 2.6 \\
N=8\end{array}$ & $\begin{aligned} 2505 & \pm 368 \\
N & =19\end{aligned}$ & $\begin{aligned} 48 & \pm 5 \\
N & =16\end{aligned}$ & $\begin{array}{l}79 \pm 7 \\
N=10\end{array}$ \\
\hline Tepoto Sud & $\begin{array}{r}152 \pm 15 \\
N=17\end{array}$ & $\begin{array}{l}27 \pm 3 \\
N=17\end{array}$ & $\begin{array}{c}2.2 \pm 0.4 \\
N=12\end{array}$ & $\begin{array}{c}0.17 \pm 0.01 \\
N=20\end{array}$ & $\begin{aligned} 6.1 & \pm 0.5 \\
N & =17\end{aligned}$ & $\begin{array}{c}5.1 \pm 0.3 \\
N=6\end{array}$ & $\begin{aligned} 1080 & \pm 192 \\
N & =16\end{aligned}$ & $\begin{array}{l}71 \pm 4 \\
N=16\end{array}$ & $\begin{array}{l}85 \pm 4 \\
N=11\end{array}$ \\
\hline Tikehau & $\begin{aligned} 244 & \pm 12 \\
N & =143\end{aligned}$ & $\begin{aligned} 23 & \pm 1 \\
N & =143\end{aligned}$ & $\begin{aligned} 2.7 & \pm 0.1 \\
N & =139\end{aligned}$ & $\begin{aligned} 0.17 & \pm 0.01 \\
N & =14.1\end{aligned}$ & $\begin{aligned} 10.8 & \pm 0.3 \\
N & =135\end{aligned}$ & $\begin{aligned} 9.4 & \pm 0.4 \\
N & =114\end{aligned}$ & $\begin{array}{r}1627 \pm 103 \\
N=110\end{array}$ & $\begin{array}{l}78 \pm 1 \\
N=123\end{array}$ & $\begin{array}{l}81 \pm 1 \\
N=4\end{array}$ \\
\hline Toau & $\begin{array}{c}158 \pm 21 \\
N=8\end{array}$ & $\begin{array}{r}23 \pm 3 \\
N=8\end{array}$ & $\begin{aligned} 2.3 & \pm 0.3 \\
N & =8\end{aligned}$ & $\begin{aligned} 0.14 & \pm 0.01 \\
N & =8\end{aligned}$ & $\begin{aligned} 7.1 & \pm 0.6 \\
N & =8\end{aligned}$ & $\begin{aligned} 10.3 & \pm 1.2 \\
N & =8\end{aligned}$ & $\begin{aligned} 1221 & \pm 234 \\
N & =8\end{aligned}$ & & \\
\hline Tuanake & $\begin{array}{l}76 \pm 3 \\
N=9\end{array}$ & $\begin{array}{l}11 \pm 1 \\
N=9\end{array}$ & & $\begin{aligned} 0.14 & \pm 0.01 \\
N & =9\end{aligned}$ & $\begin{array}{c}6.9 \pm 0.1 \\
N=9\end{array}$ & & $\begin{aligned} 571 & \pm 38 \\
N & =9\end{aligned}$ & & \\
\hline Ocean & $\begin{array}{l}44 \pm 5 \\
N=12\end{array}$ & $\begin{array}{l}10 \pm 1 \\
N=12\end{array}$ & $\begin{aligned} 0.6 & \pm 0.1 \\
N & =12\end{aligned}$ & $\begin{aligned} 0.05 & \pm 0.00 \\
N & =13\end{aligned}$ & $\begin{aligned} 5.0 & \pm 0.5 \\
N & =11\end{aligned}$ & $\begin{aligned} 15.1 & \pm 3.4 \\
N & =11\end{aligned}$ & $\begin{aligned} 1071 & \pm 154 \\
N & =11\end{aligned}$ & $\begin{aligned} 86 & \pm 2 \\
N & =11\end{aligned}$ & $\begin{array}{r}92 \pm 4 \\
N=9\end{array}$ \\
\hline
\end{tabular}

Four atoll lagoons (Rangiroa, Reka-Reka, Taiaro and Tikehau) presented a higher POC content $\leqslant 200 \mathrm{mg}$ $\mathrm{m}^{-3}$ ) and one (Tekokota) a POC concentration close to oceanic level $\left(\approx 50 \mathrm{mg} \mathrm{m}^{-3}\right)$. Other atolls presented intermediate POC concentrations. The high POC concentration observed in the Reka-Reka lagoon can be explained by the resuspension of benthic microphytes and detritus due to the shallowness of the lagoon $(1.5 \mathrm{~m})$. We observed a significant correlation (Fig. 5) between atoll lagoon average POC concentrations and its latitude $(\mathrm{r}=-0.73, \mathrm{n}=14, \mathrm{p}=0.003)$. However, the methodology used in the northern atolls (Tikehau and Rangiroa) was different from the methodology used during the TYPATOLL expedition (see 'Material and methods'). Both methods were tested together during the TY2 expedition and no significant differences appear. The correlation between POC and latitude could reflect the influence of equatorial upwelling. In- deed, Dandonneau \& Eldin (1987) considered that the position of the transition between the waters deriving from the Peruvian and equatorial upwellings, and the oligotrophic waters of the central Pacific varies between 5 and $17^{\circ} \mathrm{S}$. These authors used sea-surface chlorophyll sampling carried out by merchant ships on the Tahiti-Panama track. Between December 1979 and September 1985, the Tuamotu atolls were observed to be reached by the upwelling-derived waters on $14 \%$ of the 118 transects. They considered that the influence of rich waters on Tuamotu might help to explain the anomalous abundance of life on these atolls. We do not observe a significant decrease of oceanic water POC in relation to latitude. However, lagoonal POC content may be a good index of lagoon primary productivity, because POC integrates over a larger time than chl a. Indeed, POC turnover time is generally longer than chl a turnover time. Occasional incoming 


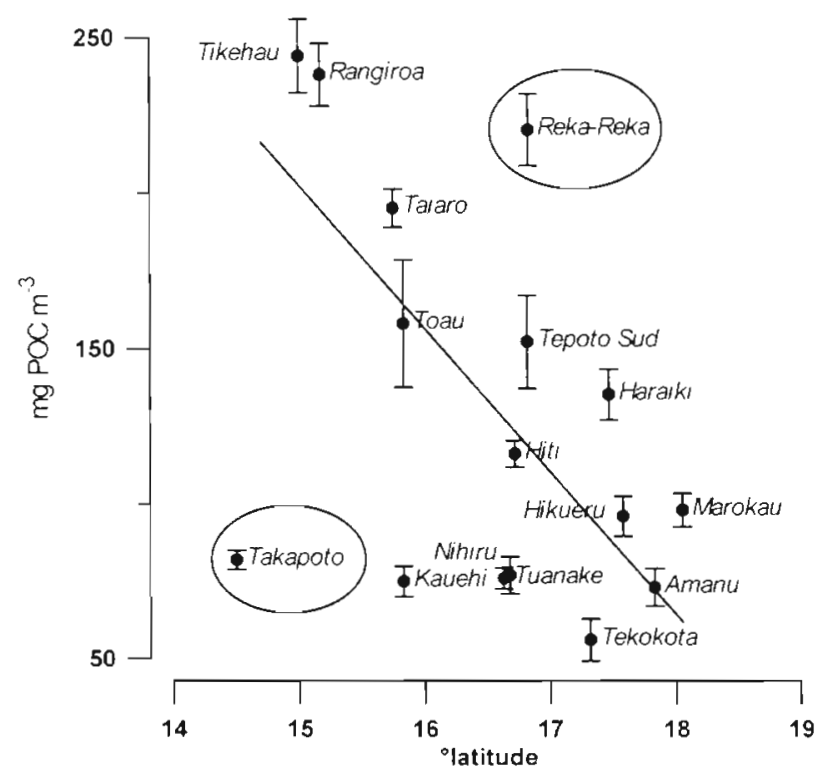

Fig. 5. Regression of average POC concentrations vs atoll latitude. Takapoto and Reka-Reka are not included in the linear regression

of rich water inside northern atoll lagoons may produce an increase in the lagoon primary production and therefore an increase in the POC standing stock. The average Takapoto lagoon POC concentration is largely below the linear regression. Takapoto, located in the north of the Tuamotu Archipelago, has no deep passage linking the lagoon and the ocean and a large residence time $(4.3 \mathrm{yr})$ Therefore, the effects of oceanic waters derived from the upwellings would be lower in this lagoon than in open atoll lagoons. In addition, the presence of numerous cultivated pearl oysters and other filter feeding organisms in Takapoto lagoons could be responsible for the relative low POC content. Indeed, the density of pearl oysters in the Takapoto lagoon appeared to exceed the nutritional potential of the lagoon (Vacelet et al. 1996).

Average chlorophyll concentrations in the atoll lagoons were inversely correlated with the 'porosity' $(r=-0.77, n=15, p=0.001 ;$ Fig. 6$)$. The 'porosity' is the ratio of the length of reef flat spillways to the total length of barrier reef. It reflects the water exchange between lagoon and ocean. The dominant effect of the residence time on primary production and phytoplankton biomass has been demonstrated in other ecosystems (Smith 1984). In One Tree Island lagoon, the amount of primary production was related to the residence time of water (Kinsey 1985). Hamner \& Wolansky (1988) demonstrated the dominant effect of hydrodynamic factors on biological processes in lagoons. Delesalle \& Sournia (1992) observed a linear relationship between residence time and phytoplankton chlorophyll concentrations in coral reef lagoons.
The increase of chlorophyll concentration with the degree of confinement of atoll lagoons may be related to a simple 'dilution' by the low-chlorophyll oceanic waters in open atolls, but also to a difference in phytoplankton community structure. Indeed, the oceanic phytoplankton community is largely dominated by Prochlorococcus and the lagoonal community by Synechococcus; the proportion of picoeukaryotes in closed atoll lagoons is also higher than in open atoll lagoons (Charpy \& Blanchot 1996, 1997).

\section{Comparison with oceanic waters}

POM concentration in surface oceanic water was 2 to 5 times lower than in atoll lagoons (except for the Tekokota lagoon). On average, surface oceanic water $C: N$ ratio $(5.0 \pm 0.5)$ was lower than the lagoonal ratio $(8.2 \pm 0.2)$. This was probably due to the lower proportion of detritus in oceanic waters. The N:P ratio seems to be higher in the ocean $(15.1 \pm 3.4)$ than in the lagoons $(9.7 \pm 0.3)$. However, that difference is not significant, because of the large standard error in this ratio in oceanic water, probably due to error in measuring POP concentration in oligotrophic waters. We would have expected the N:P ratio to be lower in the ocean. Indeed, Charpy-Roubaud et al. (1990) and Charpy (1996) demonstrated that phosphate level were significantly lower in the Tikehau and Takapoto lagoons than in surrounding surface oceanic waters. In these lagoons, the dissolved inorganic N:P is higher than in oceanic waters. In addition, Dufour \& Har-

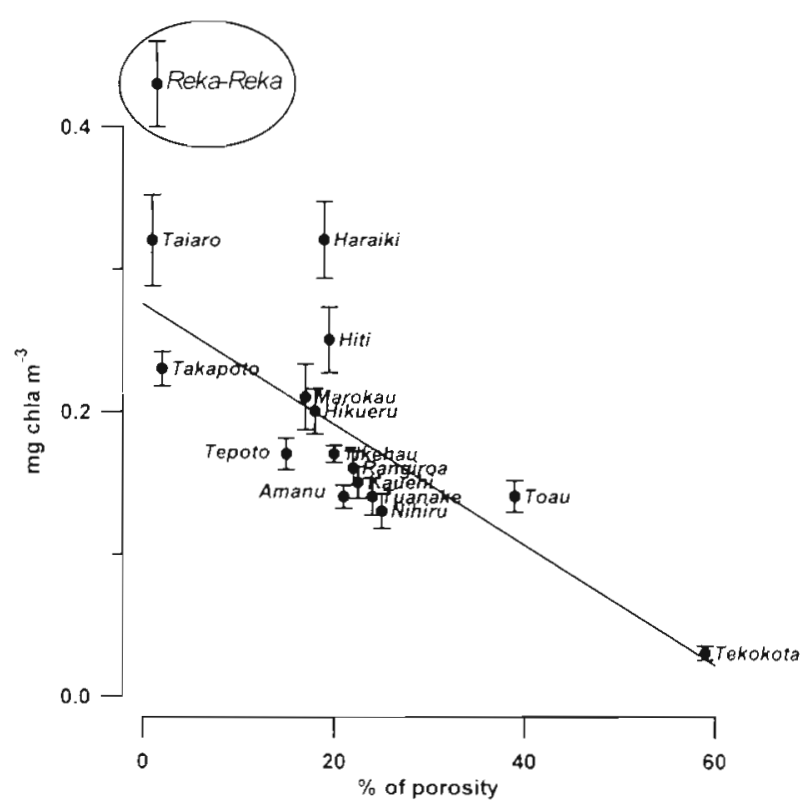

Fig. 6. Regression of average chl a concentration vs atoll porosity. Reka-Reka is not included in the linear regression 
melin-Vivien (1997) found evidence that the more the lagoons are isolated from the ocean, the more they are depleted in phosphate. The reverse can be observed for dissolved inorganic nitrogen.

The percentages of POC $<3 \mu \mathrm{m}$ and chl $a<3 \mu \mathrm{m}$ in surface oceanic waters $192 \pm 4 \%$ and $86 \pm 2 \%$ respectively) were higher than in lagoonal waters $(79 \pm 1 \%$ and $78 \pm 1 \%$ ). The small size of organic particles in oceanic waters reflects the high proportion of prochlorophytes observed in these waters by Charpy \& Blanchot (1996).

\section{Comparisons with other coral reef lagoons}

Data on POC concentrations in coral reef lagoons are sparse. Tuamotu POC concentrations were foundable in the same range as other coral reef lagoons (Table 7). The high values observed at the Houtman Abrolhos Reefs (Western Australia) are due to the extensive beds of macroalgae. Their POM export from the surf zone is of the order of 3000 to $9000 \mathrm{~g} \mathrm{C} \mathrm{m}^{-1} \mathrm{~d}^{-1}$ (Hatcher 1983). However, the absolute values of POM concentrations in coral reef lagoons reflect not only the natural variability of these parameters, but also the major errors associated with the methods employed (Hatcher 1983).

\section{POM quality}

The proportion of phytoplankton $\mathrm{C}$ to total POC is low in Tuamotu lagoons. Indeed, using the $\mathrm{C}$ : $\mathrm{Chl}$ a ratio of Table 6 and the phytoplankton C:chl a ratio of 82 determined by Charpy et al. (1992) in Takapoto, we calculate that phytoplankton $\mathrm{C}$ represents from 5\% (minimum value observed in Tikehau) to 19\% (maximum value observed in Takapoto) of the total POC of the prospected atoll lagoons. The metabolism of the numerous cultivated pearl oysters is probably responsible for the higher phytoplankton contribution to POM observed in Takapoto. Indeed, waste products from the reared Pinctada margaritifera stock in Takapoto lagoon enhanced the growth rates of phytoplankton by decreasing the regeneration time of the nutrients (Vacelet et al. 1996). Effectively, the average phytoplankton doubling rate per day was lower in Takapoto than in Tikehau (1.1 and $1.3 \mathrm{~d}^{-1}$ respectively for the $<1 \mu \mathrm{m}$ fraction, Charpy 1996). Bacterioplankton constitutes 40 to $60 \%$ of the living planktonic biomass in Takapoto and Tikehau lagoon (Dufour et al. 1996). Torréton \& Dufour (1996) have shown that a large part of the bacteria is inactive in these lagoons. Moreover, pearl oysters were capable of efficiently filtering particles $>3 \mu \mathrm{m}$, including bacterial aggregates and bac-

Table 7. Particulate organic carbon (POC $\mathrm{mg} \mathrm{C} \mathrm{m}{ }^{-3}$ ) in coral reef lagoon waters. Taken partly from Hatcher (1983) and Marshall et al. (1975)

\begin{tabular}{|c|c|c|c|}
\hline Lagoon & Lagoon & Ocean & Source \\
\hline Enewetak Atoll & $20-50$ & $18-30$ & Gerber \& Marshall (1982) \\
\hline Fanning Atoll & 80 & & Gordon (1971), Smith \& Pesret (1974) \\
\hline Canton Atoll & 160 & & Smith \& Jokiel $(1975 \mathrm{a}, \mathrm{b})$ \\
\hline Kavariti Atoll & 349 & 240 & Qasim \& Sankaranarayanan (1970) \\
\hline Houtman Atoll & $1560-3660$ & $14-42$ & Hatcher (1983) \\
\hline South Caicos & 130 & 40 & Marshall et al. (1975) \\
\hline Kanohe Bay & 420 & & Coles \& Strathman (1973) \\
\hline Lizard lsland & $82-16$ & $185-243$ & Moriarty (1979) \\
\hline New Caledonia & $222 \pm 19$ & & Clavier et al. (1995) \\
\hline Tikehau Atoll & 192 & $52 \pm 3$ & Charpy \& Charpy-Roubaud (1991) \\
\hline Great Astrolabe Reef & 145 & & Charpy et al. (1996) \\
\hline Amanu & $73 \pm 6$ & $44 \pm 5$ & This study \\
\hline Haraiki & $135 \pm 8$ & $44 \pm 5$ & \\
\hline Hikueru & $97 \pm 6$ & $44 \pm 5$ & \\
\hline Hiti & $116 \pm 4$ & $44 \pm 5$ & \\
\hline Kauehi & $75 \pm 5$ & $44 \pm 5$ & \\
\hline Marokau & $98 \pm 5$ & $44 \pm 5$ & \\
\hline Nihiru & $77 \pm 6$ & $44 \pm 5$ & \\
\hline Rangiroa & $238 \pm 9$ & & \\
\hline Reka-Reka & $221 \pm 12$ & $44 \pm 5$ & \\
\hline Taiaro & $195 \pm 6$ & $44 \pm 5$ & \\
\hline Takapoto & $82 \pm 3$ & & \\
\hline Tekokota & $56 \pm 7$ & $44 \pm 5$ & \\
\hline Tepoto Sud & $152 \pm 15$ & $44 \pm 5$ & \\
\hline Tikehau & $244 \pm 12$ & & \\
\hline Toau & $158 \pm 21$ & & \\
\hline Tuanake & $76 \pm 3$ & $44 \pm 5$ & \\
\hline
\end{tabular}


teria attached to particles. However, these larger particles are generally insignificant in lagoon water (Dufour et al. 1996). The main part of the POC consists of detritus (Charpy \& Charpy-Roubaud 1990) with a high turnover time, and more than $70 \%$ of the POM has a size smaller than $3 \mu \mathrm{m}$ and cannot be retained by adult Pinctada margaritifera. This result has to be taken into account when calculating the density of pearl oysters which can be supported by the nutritional potential of Tuamotu atoll lagoons.

\section{CONCLUSIONS}

POM in Tuamotu atoll lagoons varied between 56 and $244 \mathrm{mg} \mathrm{C} \mathrm{m} \mathrm{m}^{-3}$. The concentration increased appreciably during the austral summer. The level of POM depends strongly on the latitude of the atoll. Indeed, the northern atolls of the Tuamotu Archipelago will be enriched by nutrient-rich waters deriving from the Peruvian and equatorial upwellings. The more the lagoons are isolated from the ocean, the higher their phytoplankton biomass. POM concentration in lagoons was 2 to 5 times higher than in oceanic waters. Organic particles were larger than in the ocean, with higher $\mathrm{C}: \mathrm{N}$ and lower C:P ratios. However, $70 \%$ of the POM had a size under $3 \mu \mathrm{m}$ and these small particles would not be usable directly by the adult pearl oysters. These characteristics of the POM in atoll lagoons have to be taken into account in calculations of their biotic capacity with a view to defining the densities at which Pinctada margaritifera can be cultured. In Takapoto atoll lagoon, the high density of pearl oyster farms causes a decrease in POM content and an increase of phytoplankton biomass.

Taking into account the POM quality and quantity, the best atolls for pearl oyster farming seem to be those located in the north of the Tuamotu Archipelago (higher POM content), with small exchange with the ocean (higher phytoplankton content).

Acknowledgements. This work was carried out in French Polynesia within the framework of the PGRN, CYEL, PNRCO and TYPATOLL programs. We thank L. Lo, J.-P. Rochette and A. Pellan for technical help in the field and in the lab. This work is dedicated to Sylvain Bonnet, our friend and colleague who died in an accident in 1996, just after the last TYPATOLL expedition

\section{LITERATURE CITED}

Charpy L (1992) The CYEL program: energy flow and organic-matter cycling in atoll lagoons. UNEP Reg Seas Rep Stud 147:69-75

Charpy L (1996) Phytoplankton biomass and production in two Tuamotu atoll lagnons (French Polynesia). Mar Ecol Prog Ser 145:133-142
Charpy L, Blanchot J (1996) Prochlorococcus contribution to phytoplankton biomass and production of Takapoto atoll (Tuamotu archipelago). CR Acad Sci Ser III Life Sci 319: $131-137$

Charpy L, Blanchot J (1997) Relative contributions of Prochlorococcus and Synechococcus to phytoplankton biomass and production in eleven Tuamotu atolls (French Polymesia) Proc 8th Int Symp Coral Reef, Panama (in press)

Charpy L, Blanchot J, Lo I (1.992). Contribution des cyanobactéries (Synechococcus spp.) à la production phytoplanctonique dans un lagon d'atoll fermé (Takapoto, Tuamotu, Polynésie Française). CR Acad Sci Sér III 314:395-401

Charpy L, Charpy-Roubaud CJ (1990) Trophıc structure and productivity of the lagoonal communities of Tikehau atoll (Tuamotu Archipelago, French Polynesia). Hydrobiologia $207: 43-52$

Charpy L, Charpy-Roubaud CJ (1991) Particulate organic matter fluxes in a Tuamotu Atoll Lagoon (French Polynesia). Mar Ecol Prog Ser 71:53-63

Charpy L, Harrison N, Maata M (1.996) Nutrients and particulate organic matter in The Great Astrolabe Reef Lagoon. ORSTOM Tahiti Notes et Doc Océanogr 46:5-10

Charpy-Roubaud CJ, Charpy L, Cremoux JL (1990) Nutrient budget of the lagoonal waters in an open South Pacific atoll (Tikehau, Tuamotu, French Polynesia). Mar Biol $107: 67-73$

Chevallier JP, Salvat B (1976) Etude géomorphologique et biologique de l'atoll fermé de Taiaro (Tuamotu, Polynésie Française). Cah Pac 16:169-202

Clavier J, Chardy P, Chevillon C (1995) Sedimentation of particulate matter in the south-west lagoon of New Caledonia: spatial and temporal patterns. Estuar Coast Shelf Sci 40:281-294

Coles SL, Strathmann R (1973) Observations on coral mucus 'flocs' and their potential trophic significance. Limnol Oceanogr 18:673-678

Dandonneau Y. Eldin G (1987) Southwestward extent of chlorophyll-enriched waters from the Peruvian and Equatorial upwellings between Tahiti and Panama. Mar Ecol Prog Ser 38:283-294

Delesalle B, Sournia A (1992) Residence time of water and phytoplankton biomass in coral reef lagoons. Cont Shelf Res 12:939-949

Dufour P. Harmelin-Vivien M (1997) A research program for a typology of atoll lagoons: strategy and first results Proc 8th Int Symp Coral Reef, Panama (in press)

Dufour P, Torréton J-P Jonquière G (1996) Utilization of bacterioplankton as a food source by the pearl oyster Pinctada margaritifera. In: Lessios HA (ed) Proc 8th Int Symp Coral Reef, Panama, Abstracts, p 54

Gerber RP, Marshall N (1982) Characterization of the suspended particulate organic matter and feesding by the lagoon zooplankton. at Enewetak atoll. Bull Mar Sci 32: $290-300$

Gordon DC Jr (1971) Organic carbon budget of Fanning Island lagoon. Pacif Sci 25:222-227

Gordon DC Jr, Sutcliffe WH Jr (1973) A new dry combustion method for the simultaneous determination of total organic carbon and nitrogen in sea water. Mar Chem 1:231-244

Hamner WM, Wolanskj. E (1988) Hydrodynamics forcing functions and biological processes on coral reefs: a status review. Proc 6th Int Symp Coral Reef. Townsville 1:103-114

Hatcher BG (1983) The role of detritus in the metabolism and secondary production of coral reef ecosystems. In: Baker JT et al. (eds) Proc Great Barrier Reef Conference. Australian Inst Mar Science, Townsville, p 317-325 
Intes A, Caillart B, Charpy L, Charpy-Roubaud C, Lemasson L, Morize E (eds) (1994) Tikehau. An atoll of the Tuamotu Archipelago (French Polynesia). Atoll Res Bull 415:1-110

Kinsey DW (1985) The functional role of back-reef and lagoonal systems in the central Great Barrier Reef. In: Gabrie C, Toffard JL, Salvat B (eds) Proc 5th Int Coral Reef Congr Abstracts, Tahiti 2: 203

Marshall N, Durbin AG, Gerber R, Telek G (1975) Observations on particulate and dissolved organic matter in coral reef areas. Int Revue Ges Hydrobiol 60:335-345

Menzel D, Corwin J (1965) The measurement of total phosphorus in sea water based on the liberation or organically bound fraction by persulfate oxidation. Limnol Oceanogr 10:280-282

Moriarty DJW (1979) Biomass of suspended bacteria over coral reefs. Mar Biol 53:193-200

Poli G. Salvat B (1976) Etude bionomique d'un lagon d'atoll totalement fermé: TAIRAO. Cah Pac 19:227-252

Pujo-Pay M, Raimbault P (1994) Improvement of the wetoxidation procedure for simultaneous determination of particulate organic nitrogen and phosphorus collected on filters. Mar Ecol Prog Ser 105:203-207

Qasim SZ, Sankaranarayanan VN (1970) Production of particulate organic matter by the reef on Kavaratti atoll (Laccadives). Limnol Oceanogr 15:574-578

Ricard M (1985) Rangiroa atoll, Tuamotu Archipelago. Proc 5th Int Coral Reef Congr, Tahiti 1:159-209

Salvat B, Richard G (1985) Atoll de Takapoto, Archipel des Tuamotu. Proc 5th int Coral Reef Congr, Tahiti 1:325-377

Smith SV (1984) Phosphorus versus nitrogen limitation in the marine environment. Limnol Oceanogr 29:1149-1160

This article was submitted to the editor
Smith SV, Jokiel PL (1975a) Water composition and biogeochemical gradients in the Canton atoll lagoon: 1 Lagoon description; design of system analysis; salt and water budget. Mar Sci Communs 1:75-100

Smith SV, Jokiel PL (1975b) Water composition and biogeochimical gradients in the Canton atoll lagoon: 2 Budgets of phosphorus, nitrogen, carbon dioxide, and particulate materials. Mar Sci Communs 1:165-207

Smith SV, Pesret F (1974) Processes of carbon dioxide flux in the Fanning island lagoon. Pacif Sci 28:225-245

Stoddart DR (1969) Reconnaissance geomorphology of Rangiroa atoll, Tuamotu archipelago. Atoll Res Bull 125:1-44

Strickland JDH, Parsons TR (1972) A practical handbook of seawater analysis, 2nd edn. Bull Fish Res Bd Can 167:1-311

Torréton JP, Dufour P (1996) Bacterioplankton production determined by DNA synthesis, protein synthesis and frequency of dividing cells in Tuamotu atoll lagoons and surrounding ocean. Microb Ecol 32:185-202

Torréton JP, Dufour P (1997) Temporal and spatial stability of bacterioplankton biomass and productivity in an atoll lagoon. Aquat Microb Ecol 11:251-261

Tréguer P, Le Corre P (1975) Manuel d'analyses des sels nutritifs dans l'eau de mer. Laboratoire d'Océanographie Chimique, Université de Bretagne Occidentale, Brest

Vacelet E, Arnoux A, Thomassin B (1996) Particulate material as an indicator of pearl-oyster excess in the Takapoto lagoon (Tuamotu, French Polynesia). Aquaculture 144 133-148

Yentsch CS, Menzel DW (1963) A method for the determination of phytoplankton chlorophyll and phaeophytin by fluorescence. Deep Sea Res 10:221-231

Manuscript first received: December 20, 1996

Revised version accepted: March 5, 1997 